\title{
Predicting U.S. College Students' Interest in Studying in China: Social Influence, Personal Experiences, Country Reputation, and Media Coverage
}

\author{
Hongwei Yang \\ Yingqi Wang \\ Appalachian State University
}

\begin{abstract}
:
An online survey of 374 US college students was conducted in April, 2015 to examine whether and how subjective norm, direct and indirect experiences related to China, their perceptions of China (China's country reputation), and media coverage of China influence their interests of studying in China. Statistical results show that their subjective norm, China's reputation, and media coverage of China positively predicted their attitudes toward studying in China $\left(\mathrm{R}^{2}=51.5\right)$, whereas their intent to study in China $\left(\mathrm{R}^{2}=35.2\right)$ was determined by their attitudes, subjective norm, and China experiences. The study indicates that social influence or normative pressure is a much more important factor to shape their attitudes toward studying in China than their overall perceptions of China and media coverage of China. Social influence is also the second most significant predictor of their intent to study in China. The important theoretical and practical implications are discussed.
\end{abstract}

Following the exponential growth of China's economy in the past two decades, the number of international students in China has been on the rise steadily (Liu, 2014). The total international student enrollment in China surged from 110,844 in 2004 to 377,054 in 2014. Similarly, the number of U.S. college students studying in China had increased rapidly from 10,299 in 2005 to 25,312 in 2013 and the United States had become the No. 2 sending country since 2008, second only to South Korea (MOE, 2017). However, since 2013, a slow declining trend set in, suggesting a dwindling interest among US college students, as the number of US college students in China dropped to 23,838 in 2016 (MOE, 2017). At the same time, the number of U.S. students who chose China as their destination for study abroad decreased by $8.6 \%$ in 2016, while the total number of Americans studying abroad grew by $3.8 \%$ over the prior year (IIE, 2017).

Both the U.S. and Chinese governments have considered educational exchanges as a powerful strategy of public diplomacy by encouraging international students to study in the USA/China and sending U.S./Chinese students abroad as citizen ambassadors. A country's institutions of higher education are viewed as sites of national image-construction (Wang, 2011). In November, 2009, U.S. president Barack Obama announced the "100,000" strong initiative to increase the number and diversify the composition of American students studying in China. The goal of supporting 100,000 
students to study in China was achieved in July, 2014 (The 100,000 Strong Foundation, 2015). Annually, the Chinese government offers about 20,000 scholarships for U.S. students to study in China (Jue, 2010; Shambaugh, 2015). The Chinese government planned to attract 500,000 international students to study in higher education institution, elementary and secondary schools in Mainland China by 2020 (MOE, 2012). In the recent years, China's educational exchanges initiatives have been especially successful in developing countries in Asia, Africa and the Americas (Liu, 2014; Siow, 2015). Nevertheless, a report produced by Education Intelligence, the British Council's global higher education research service, found that only $1 \%$ of American and British students interested in study-abroad options wanted to go to China, after polling more than 10,000 students in both the U.S. and U.K. (Chen, 2014). According to the IIE (2017), only 3.6\% of U.S. students chose China as their study abroad destination in 2016. The low interest of U.S. college students in studying in China and low market share of China in international student market baffle the mind of international education scholars and policy makers.

A big majority of U.S. colleges and universities has listed the goal of preparing globally oriented and interculturally competent graduates as one of their important goals of higher education. One study showed that $85 \%$ of top-ranked national universities and $68 \%$ of top-ranked liberal arts colleges in the U.S. considered the development of intercultural competence as one of their primary higher education objectives (Stemler, 2012). Most employers believed that U.S. colleges should place greater emphasis on improving college students' ability to understand the global context of situations and decisions (AAC\&U, 2010). One of the best options to cultivate the global awareness and intercultural competence of U.S. college students is the study abroad programs offered by over 90\% of US colleges and universities (Hoffa \& DePaul, 2010; Twombly, Salisbury, Tumanut, \& Klute, 2012). To date, many education scholars agree that U.S. college students' time abroad is a lifechanging educational experience with many short-term and long-term benefits to enhance their competitiveness in an increasingly diverse and globalized world (e.g., Williams, 2005; Paige et al., 2009). Most of empirical studies to measure the short-term effects of cross-border education linked studying abroad to significant personal changes in attitudes, intercultural and international awareness, self-efficacy, independence and other indicators of personal growth (e.g., Black \& Duhon, 2006; Cai \& Sankaran, 2015; Jochum, 2014). Some studies also demonstrated the long term impacts of studying abroad such as the increase of foreign languages fluency, intercultural competencies or sensitivity, global or civic engagement, knowledge production, philanthropy, social entrepreneurship (e.g., Hansel, 2008; Paige et al., 2009; Murphy et al., 2014). Accordingly, to study in China will help U.S. college students achieve those beneficial outcomes (e.g., Dixon, 2013), in light of China's growing economic and political powers. The world has witnessed the phenomenal rise of China as the second largest economy in recent years. The double digit growth of China's real GDP in 1990s and 2000s was hailed as a miracle and lifted millions of people out of poverty (Morrison, 2015). Since 2015, China has become the largest trading partner of the United States with a total trade value of $\$ 578.6$ billion in 2016 (U.S. Census, 2016). The importance of U.S. and China economic and political relationships has attracted a lot of serious attention from policy makers and scholars in the United States and Asia-Pacific countries (e.g., Li, 2011; Meijer, 2015; Oh, 2012; Saunders, 2014). Why are many US college students not motivated to consider China as their preferred destination for studying abroad? 
Previous studies have revealed some barriers and obstacles that refrained U.S. college students from choosing China for their international education. U.S. students are said to prefer more familiar and closer destinations (Chen, 2014). Chinese universities remain unknown in the United States with only three Chinese institutions featured in the Times Higher Education's ranking of the world's top 100 universities (Shambaugh, 2015). Other possible explanations of U.S. students' low interest in China as a study-abroad destination include traditionally unfavorable coverage of China in the U.S. media (Wang \& Shoemaker, 2011; Zhao, 2014) and negative views of China among Americans (Wang, 2011). Nevertheless, no empirical study can be retrieved from U.S. and Chinese databases of academic journals that attempted to connect these influence factors directly with U.S. college students' attitudes toward and intent of studying in China.

The present study is intended to examine whether and how U.S. college students' subjective norm, personal experiences related to China, exposure to media coverage of China, and perceptions of China influence their attitudes toward and intent of studying in China, in the context of an online survey of 374 U.S. college students.

\section{Theoretical Framework}

Literature Review on Study Abroad and Study in China

Our current research considers studying abroad as a high involvement service that is time consuming, cost-intensive, but has life changing outcomes (Morrish \& Lee, 2011; Srikatanyoo \& Gnoth, 2002). We regard U.S. college students as rational consumers of higher education who are capable of making wise decisions after weighing the benefits and costs of studying abroad, based on previous studies (e.g., Finney \& Finney, 2010; Obermiller, Fleenor, \& Raven, 2005; Watjatrakul, 2010).

Previous studies on motivations of education abroad show that, when considering study abroad opportunities, U.S. college students are driven by such facilitators as: (1) the desire to improve understanding of other countries and cultures (Kuzma, Kuzma, \& Thiewes, 2012; Luo \& JamiesonDrake, 2015; Movassaghi, Unsal, \& Göçer, 2014); (2) the motivation for personal growth (Hackney, Boggs, \& Borozan, 2012; Movassaghi et al., 2014; Pope et al., 2014); (3) subjective norm including parental and peer influences (Brux \& Fry, 2010; Fornerino, Jolibert, Sánchez, \& Zhang, 2011; Salyers et al., 2015; Shirley, 2006), (4) professional and career development (Fornerino et al., 2011; Salyers et al., 2015), (5) having fun or seeking pleasure (Fornerino et al., 2011), (6) faculty or administrative support (Salyers et al., 2015), (7) improving social status (Fornerino et al., 2011), (8) meeting new friends and contacts (Kuzma et al., 2012), and (9) having a good friend or relative in a foreign country (Nyaupane, Paris, \& Teye, 2011). These studies usually applied the classic push-pull model of international student motivation (Altbach, 2004; Mazzarol \& Soutar, 2002).

Recent research also indicates that study abroad participants are more likely to be female, white, to major in the humanities or social sciences, and to study in liberal arts colleges than male, minority students, natural science and engineering majors, and those studying at research universities, regional institutions, and community colleges (e.g., Luo \& Jamieson-Drake, 2015; Salisbury et al., 2009; Salisbury, Paulsen, \& Pascarella, 2010, 2011; Stallman et al., 2010; Twombly et al., 2012). 
The inhibiting factors for education abroad were identified as follows: (1) lack of foreign language interest or knowledge (Deviney, Vrba, \& Mills, 2014; Goldstein \& Kim, 2006), (2) costs of time or opportunities such as delay of graduation, loss of job/internship opportunity (Shirley, 2006), (3) financial restraints (Brux \& Fry, 2010; Deviney et al., 2014; Gordon, Patterson, \& Cherry, 2014; Matthews, Hameister, \& Hosley, 1998; Toncar, Reid, \& Anderson, 2005; Schnusenberg, de Jong, \& Goel, 2012), (4) lack of awareness or information about study abroad programs (Matthews et al., 1998), (5) concerns about safety or security (Deviney et al., 2014; Gertner, 2011; Gordon et al., 2014); (6) academic issues such as credit transfer, completion of one's major, and the program fit (Goldstein \& Kim, 2006; Toncar et al., 2005); and (7) lack of faculty/administrative support (Gordon et al., 2014; Matthews et al., 1998).

Current research on cross-border education demonstrates that U.S. college students can garner the following short-term benefits from their international education experiences: (1) sophisticated cognitive skills such as critical/creative thinking and problem solving skills (Cai \& Sankaran, 2015; Cho \& Morris, 2015; Lee, Therriault, \& Linderholm, 2012), (2) improved intercultural competencies (Pedersen, 2010; Stemler, Imada, \& Sorkin, 2014; Williams, 2005), (3) intercultural awareness, sensitivity, and openness (Black \& Duhon, 2006; Braskamp, Braskamp, \& Merrill, 2009; Rexeisen et al., 2008; Williams, 2005), (4) advanced second-language skills (Duperron \& Overstreet, 2009; Jochum, 2014), (5) increased interest in international economic, political, and cross-cultural issues (Paige et al., 2009; Ryan \& Twibell, 2000), (6) higher commitment to peace and international cooperation, and greater friendliness for visiting foreign nationals (Gary et al., 2002; Nesdale \& Todd, 1993), (7) enhanced personal development and global citizenship (Geelhoed et al., 2003; Wynveen et al., 2012), (8) better academic performance such as higher engagement and graduation rates (Dolby, 2004, 2007; Luo \& Jamieson-Drake, 2015; Posey, 2003; Vande Berg, 2007)

In addition, several studies have identified many long term impacts of study abroad experiences including some lasting qualities of personal development (outgoing, independent, friendly, selfassured, uninhibited, worldly, open etc.); sustained interest in international affairs; improved intercultural competencies such as intercultural communication skills and intercultural sensitivity; increased foreign language proficiency and knowledge of foreign countries (AIFS, 2013; DeGraaf et al., 2013; Franklin, 2010; Hansel, 2008); the higher levels of civic engagement, knowledge production, philanthropy, social entrepreneurship, voluntary simplicity, and participation in internationally-oriented activities for personal enjoyment or leisure (DeGraaf et al., 2013; Paige et al., 2009; Murphy et al., 2014); and better educational or career choices (DeGraaf et al., 2013; Hansel, 2008; Paige et al., 2009; Mulvaney, 2017).

Many U.S. and Chinese scholars have examined the motivations or benefits or challenges or satisfaction of studying in China among international students (e.g., Bian, 2013; Ding, 2016; Dixon, 2013; English, Allison \& Ma, 2016; Foster, 2001; Jiani, 2017; Li, 2015; Li, Guo, \& You, 2017; Song \& Liu, 2014; Wen et al., 2013), whereas quite a few studies focused specifically on U.S. college students. Almost all studies involving U.S. college students were conducted to assess their learning outcomes or barriers or challenges as a result of a short-term study abroad program in China so as to tease out effective pedagogies (e.g., Bai, Larimer \& Riner, 2016; Chen, 2008; Core, 2017; Diao, 2016; Cai \& Sankaran, 2015; Deans, 2011; Du, 2013; Du, 2015; He \& Qin 2017; Liu, 2009; Lumkes, Hallett, \& Vallade, 2012; Riggan et al., 2011). It is also noteworthy that a lot of these studies are 
concerned with Chinese language acquisition (e.g., Diao, 2016; Du, 2013; Du, 2015; Foster, 2001; He \& Qin, 2017; Liu, 2009). Corroborating previously reviewed studies, research showed that, after their visit, U.S. college students reported very similar short-time benefits and long-term impacts such as Chinese language proficiency (Du, 2013; Foster, 2001; Liu, 2010), development of intercultural competences (Bai et al., 2016; Li, 2015), improved critical thinking skills (Cai \& Sankaran, 2015), increased global learning (Core, 2017; Lumkes et al., 2012), personal growth (Du, 2015; Riggan et al., 2011), and professional career development (Deans, 2011; He \& Qin, 2017). Only a few researchers investigated the antecedents or influencers or predictors of study abroad attitudes, intent and behavior among international students in China. They revealed that international students were influenced and/or motivated to study in China by China's rapid economic development, good bilateral economic relationships, high quality of China's education (especially in science and technology), mutual recognition of academic credentials and degrees (Liu, Wang, \& Hung, 2013; Song \& Liu, 2014; Jiani, 2017), government support for international education and educational cooperation, competitive advantage, maintaining and pursuing Chinese cultural identity (Fang, 2015, Jiani, 2017), bright prospects of learning the Chinese language, the desire of experiencing a different culture, and professional career development (Li, 2017; Liu et al., 2013; Jiani, 2017). However, almost no empirical study was conducted to discover the factors influencing U.S. college students' attitudes toward, intent, and behavior of studying in China except Yang's (2016) narrative study of one American student.

In addition, our extensive research in U.S. and Chinese databases of academic journals did not yield any quantitative study that integrated the theory of planned behavior, country image theory, and media theory of cultivation effects to examine the influence of subjective norm, personal experiences, China reputation, and media coverage on U.S. college students' attitudes toward and intent of studying in China. The current study intends to fill the gap of the extant research literature and to make some original contributions to study abroad theories and practices.

\section{The Theory of Planned Behavior and Study Abroad}

Ajzen (1991) proposed the Theory of Planned Behavior (the TPB) to explain people's intentions to perform different kinds of behaviors. He contends that people's behavior is primarily driven by their intention which can be predicted with high accuracy from attitudes toward the behavior, subjective norms, and perceived behavioral control (Ajzen, 1991). In the case of studying in China, attitude is defined as a college student's overall evaluation of the desirability of studying in China while subjective norm refers to a student's perception of the expectations of important people in his/her life (parents and good friends) about studying in China. Subjective norm and normative pressures are used interchangeably in this study. Perceived behavioral control, in the context of international education, means that one has sufficient means and resources to study abroad. Thus, perceived behavioral control can be substituted by a college student's annual family income and monthly personal income in this study.

The TPB will be adopted in this study to investigate U.S. college students' attitudes toward and intent of studying in China. The TPB has been widely adopted to predict consumers' intention to purchase products (e.g., Lin, 2013; Tang, Luo, \& Xiao, 2011) and intention to adopt new services such as e-commerce and mobile services (e.g., Pavlou \& Fygenson, 2006; Yang, 2013). Armitage and Conner (2001) conducted a meta-analysis of 185 independent psychological studies and concluded 
that the TPB explained $27 \%$ and $39 \%$ of the variance in behavior and intention. As far as innovation adoption is concerned, the most recent quantitative review of information systems research concluded that attitude and behavior were highly correlated with $r=.53$ (Weigel et al., 2014).

Moreover, quite a few studies have successfully employed the TPB to examine U.S. college students' intent and behavior of studying abroad (e.g., Fitzsimmons, Flanagan, \& Wang, 2013; Kang \& Megehee, 2014; Presley, Damron-Martínez, \& Zhang, 2010; Schnusenberg et al., 2012).

Based on the review of related studies above, this study posits that:

\section{H1: U.S. college students' attitudes toward studying in China positively predict their}

intent of studying in China.

\section{H2: U.S. college students' subjective norm positively predicts their (a) attitudes toward}

\section{studying in China and (b) intent to study in China.}

\section{Prior Experiences with Foreign Cultures/Countries}

In this study, prior experiences with China were operationalized as one's previous travel experience in China, participation in cultural events related to China (such as Chinese New Year celebrations), viewership of sporting events related to China (such as Beijing 2008 Olympic Games and Nanjing 2014 Youth Olympic Games), and indirect experiences with China through family members and friends. Although a few studies could not find any relationship between previous international experience and participation in study abroad (e.g., Goldstein \& Kim, 2006), most studies demonstrate that the prior experience of international travel or cross-border education is a positive predictor of a student's desire to study abroad (e.g., ACE, 2008; Hackney et al., 2012; Lewis \& Niesenbaum, 2005; Owen et al., 2013; Pope et al., 2014).

Research suggests that participation of cultural or sporting events related to a foreign country will foster positive attitudes toward and intent of studying in the country (e.g., Heslop, Nadeau, \& O’Reilly, 2010; Manzenreiter, 2010). Previous studies also revealed a strong motivation of study abroad - the desire to learn more about a different culture and a foreign country (Kuzma, Kuzma, \& Thiewes, 2012; Luo \& Jamieson-Drake, 2015; Movassaghi, Unsal, \& Göçer, 2014). It is safe to assume that participants of cultural or sporting events related to a foreign culture such as Chinese New Year's celebration share the same desire to improve their understanding of a different culture and a foreign country. Indeed, some scholars contend that linguistically and culturally prepared students are more likely to maximize their learning opportunities in foreign countries (e.g., Allen \& Dupuy, 2012; Goldoni, 2015). The participation of cultural or sporting events related to a foreign country may become a catalyst for favorable attitudes toward and intent of studying abroad.

Family members and friends' satisfactory experiences with a foreign country may also enhance one's favorable attitudes toward and intent of studying in the country. Research shows that family members and friends can exert powerful influences on college students' motivations, perceptions and intent of studying abroad (Brux \& Fry, 2010; Fornerino et al., 2011; Nguyen, 2014; Salyers et al., 2015; Shirley, 2006). Some studies on the long-term impacts of cross-border education found that international education alumni are more likely to encourage their children to study abroad (e.g., Hansel, 2008). Hence, we hypothesize that: 


\section{H3: U.S. college students' direct and indirect experiences with China positively predict}

\section{their (a) attitudes toward and (b) intent of studying in China.}

\section{Country Reputation, Media Coverage, and Study Abroad}

Country reputation, country image, and study abroad. Based on previous studies on country image (CI), country-of-origins (COO) image, and nation branding, we conceptualize a country's reputation as the sum of general perceptions, beliefs and attitudes that people have formed overtime about a country (Anholt, 2009). Thus, country reputation and country image are used interchangeably in this study, referring to a broader view of country image in marketing and business literatures (e.g., Lala, Allred, \& Chakraborty, 2009; Parameswaran \& Pisharodi, 2002; Pereira, Hsu, \& Kundu, 2005; Rojas-Méndez, 2013).

In the present study, China's reputation is operationalized as 20 characteristics measuring four dimensions (feelings about China, perceptions about China's economy, beliefs about Chinese culture and environment, and impressions of the Chinese government), adapting from the most recent scales of country reputation (Passow, Fehlmann \& Grahlow, 2005; Ponzi, Fombrun, \& Gardberg, 2011; Reputation Institute, 2012; Yang et al., 2008).

According to Reputation Institute (2012), reputation of a country is formed through (1) direct experiences of stakeholders (e.g., travel); (2) knowledge of what country does and says (e.g., branding, marketing, public relations, and politics); and (3) exposure to what others say about it (e.g., traditional and social media, NGOs, politicians, friends, and family). The more positive those three factors are, the more people are interested in visiting, living, working, studying in or buying from the country.

Hundreds of marketing and business studies on the country image or country-of-origins effect show that consumers' general perceptions of a country's image (reputation) have significant positive or negative influences on their product/advertising evaluations and intent to purchase a brand, a product, or a service. For excellent reviews of the literature on CI or COO effect, please refer to Pharr (2005) and Bloemer, Brijs, \& Kasper (2009).

Although limited research has examined the country image (reputation) effect on U.S. college students' study abroad attitudes and intent, existing studies of international education have revealed a significant, positive connection between the country image (reputation) and the decision to study abroad (e.g., Cubillo, Sánchez \& Cervino, 2006; Cubillo-Pinilla et al., 2009; Morrish \& Lee, 2011; Srikatanyoo \& Gnoth, 2002; Yang \& Wang, 2017; Zatepilina-Monacell \& Kinsey, 2013). Studies suggest that the country of origin of prestigious universities (e.g., those in the Ivy League) is not the most important aspect in the decision-making of international consumers to choose those universities. However, the less familiar are potential students (and their parents) with a specific university, the more likely they will rely on the reputation of the university's country of origin (Cubillo-Pinilla et al., 2009; Srikatanyoo \& Gnoth, 2002). Therefore, it is expected that:

H4: U.S. college students' perceptions of China (China's reputation) positively predict their (a) attitudes toward and (b) intent of studying in China. 
Media coverage, country reputation, and study abroad. In this study, the construct of media coverage was broadly defined as a consumption of news, analysis, commentary, entertainment and sports about China in U.S. and international media such as TV/radio programs, websites, films, newspapers, magazines and books. The construct also included both traditional and new media outlets.

Public diplomacy scholars argue that country reputation management entails three levels of engagement: mediated public diplomacy, nation brands/reputation level, and the relational level (e.g., Golan, 2014). They contend that a big majority of foreign citizens receive their information about any nation from mass media outlets as most of them usually are not exposed to or participate in many different kinds of educational and cultural exchanges that help build a nation's soft power (e.g., Bennett \& Paletz, 1994; Golan, 2006). Therefore, the fundamental relationship between any government and foreign publics occurs, first and foremost, through mass media channels (Golan, 2014). Media effects on the country reputation are also discussed in the nation/place branding literature (Anholt, 2009, 2015; Fullerton et al., 2007; Rivas, 2011).

Cultivation scholars also believe that foreign citizens' perceptions of a country are greatly shaped by their vicarious experience and perceptions of a particular country in mass media (e.g., Gerbner \& Gross, 1976; Shrum et al., 1991). Communication research has confirmed that people's perceptions of foreign countries are under the strong influence of media coverage (e.g., Song \& Sung, 2013; Wang \& Shoemaker, 2011; Zhang \& Meadows, 2012). For example, previous studies demonstrate that people's general perceptions, beliefs, attitudes and social stereotypes regarding the USA (U.S. country image) are derived primarily from U.S. media products, especially television programs, films, and newspapers (e.g., Harris \& Krafta, 1999; Randolph, Fullerton, \& Kendrick, 2010).

Numerous tourism studies demonstrate that the consumption of foreign media products, especially films and TV programs, can enhance viewers' intent to visit a destination/country, and positively predict their actual visits (e.g., Im \& Chon, 2008; Iwashita, 2009; Mitchell \& Stewart, 2012). In the context of international education, a few studies also demonstrated the media influence on young students' attitudes toward and intent of studying abroad (e.g., Li, 2017; Yang \& Wang, 2017; Zatepilina-Monacell \& Kinsey, 2013).

Based on the previous studies reviewed before, we proposed the following hypotheses:

H5: U.S. college students' exposure to media coverage of China positively predicts their perceptions of China (China's country reputation).

H6: U.S. college students' exposure to media coverage of China positively predict their (a) attitudes toward and (b) intent of studying in China.

Figure 1 summarizes and presents all six proposed hypotheses. 


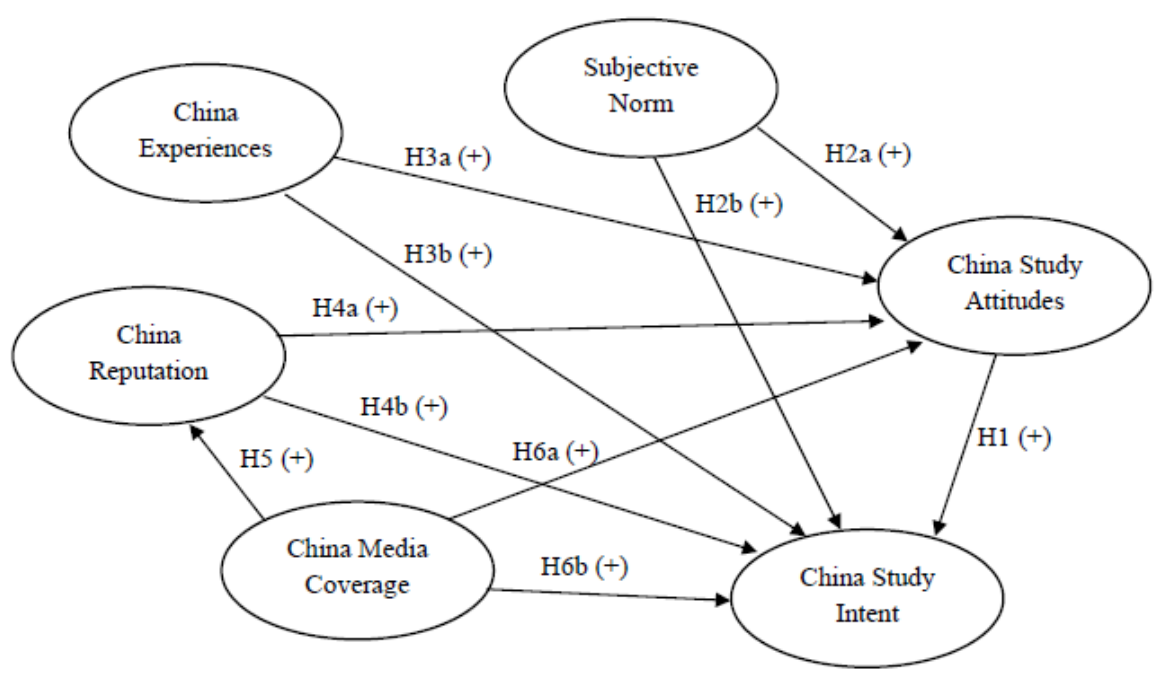

Figure 1. The Conceptual Model of Predicting Studying Abroad Attitudes and Intent

\section{Method}

An online survey was administered on www.qualtrics.com in April, 2015 to collect data from undergraduate students at a big public university in a U.S. Southeastern state with a large majority of White residents (71\%), a sizable percent of Black or African Americans (22\%) and a small percent of Asians (2.9\%). Online survey is an appropriate research method frequently adopted by international education scholars and researchers (e.g., Cho \& Morris, 2015; DeGraaf et al., 2013). A college student sample is appropriate as well-educated young adults are more likely to consider pursuing advanced studies in foreign countries than their peers. The state university is a Master's comprehensive regional university with an enrollment of over 18,000 students. Although the student population is not very racially diverse (minority students make up 16\%), its Quality Enhancement Plan is global learning and the participation rate for study abroad is $25 \%$ compared to the national rate of $14 \%$. While there is a very small community of Asians and Asian Americans in the college town, the university sponsors at least five programs for studying in China.

After the approval of the Institutional Review Board (IRB), a pilot online survey was tested among 30 students. When minor revisions were done, a solicitation letter was emailed to 3,000 randomly selected students, followed by two additional email remainders at a three-day interval. To boost the response rate, an incentive was offered and conspicuously announced that one participant would be chosen in a random drawing to receive a $\$ 100$ Amazon online gift certificate after the survey. Studies show that cash and non-cash incentives can significantly increase the response rates of both mail surveys and Web-based surveys (e.g., Dillman, 2007). After three e-mail requests, 374 responses were collected in eleven days, resulting in a response rate of $12.5 \%$. The response rate is comparable to many web surveys with email contacts among college students (e.g., Valenzuela et al., 2009; van Veen, Göritz, \& Sattler, 2016). The cases with a lot of missing data were deleted and some missing values in a few cases were replaced by the linear trend at point method (Little, 1992). The cleaned survey data were subject to statistical analyses including t-test, partial correlation analysis, multiple regression analyses, and structural equation modeling (SEM) with SPSS-22 and Amos-22. 
The survey questionnaire consists of 65 questions (see Appendix A). Perceptions of China (China Reputation) were tapped by a 20-item scale that integrated the Reputation Institute's (2012) Country Rep'Trak scale, Passow et al.'s (2005) Country Reputation Index, and Yang et al.'s (2008) Country Reputation Scale. These items measuring China's reputation include "I admire China," "China is an important contributor to global economy," "China is a beautiful country," "China has a rich historical past," and "China is run by an effective government." The exposure to media coverage on China (nine items) was specifically developed for this project based on past research (e.g., Wang \& Shoemaker, 2011; Zhao, 2014). Inspired by Yang et al.'s (2008) study of South Korea, we created a five-item scale to investigate one's direct and indirect experiences with China: visiting China, using Chinese made products (omitted), participating in China-related cultural and sporting events, hearing about China from family members or friends. Following the example of Yang et al. (2008), we also measured participants' knowledge about China by asking eleven questions but this construct was omitted from further statistical analyses as it did not correlate with any dependent variable significantly. Based on previous studies (e.g., Terry \& Hogg, 1996), we developed a five-item scale to understand one's subjective norm of studying in China: to what extent their parents and friends approve and support their wish to study in China. The scales measuring our respondents' attitudes toward and intent of studying in China were also derived from previous studies (e.g., Fitzsimmons et al., 2013; Presley et al., 2010 \& Schnusenberg et al., 2012). Four questions examined their attitudes, including "I like the idea of studying in China," and "Generally, I believe that it would be good for me to study in China." Four questions were asked to measure their intent, such as "I intend to study in China in a year or so," and "I would recommend studying in China to my friends." We also asked five demographic questions about their gender, age, race, family income (socioeconomic status) and personal income. They were considered control variables for multiple regression analyses and not included in the structural equation modeling.

Table 1. Construct reliability and EFA results

\begin{tabular}{lll}
\hline Construct & Cronbach $\boldsymbol{\alpha}$ & Variance Explained* \\
\hline Exposure to Media Coverage on China & .813 & $41.1 \%$ \\
Experiences related to China & .638 & $31.5 \%$ \\
Subjective norm & .903 & $63.3 \%$ \\
China Reputation & .882 & $50.9 \%$ \\
Attitudes toward studying in China & .915 & $73.8 \%$ \\
Intent to study in China & .810 & $61.5 \%$ \\
\hline
\end{tabular}

Note. $\mathrm{N}=374$. Exploratory factor analysis with maximum likelihood estimation and promax rotation. *Extracted sums of squared loadings.

The composite reliability analyses and exploratory factor analyses (EFA) were employed to determine the dimensionality of six key constructs. Table 1 presents the Cronbach coefficients $(\alpha)$ of six multi-item scales and the EFA results. The maximum likelihood estimation with promax rotation was adopted for the EFA as we expected some correlation among different factors of six constructs (Costello \& Osborne, 2005). The performance of five scales is deemed satisfactory $(\alpha>$ $0.70)$, and the reliability of China experiences scale is acceptable $(\alpha>0.60)$ (Nunnally \& Bernstein, 1994). In addition, the extracted variance of four concepts exceeded the 0.50 recommended level (Fornell \& Larcker, 1981). To cross-validate these findings, confirmatory factor analyses (CFA) were conducted to fit the measurement models of six multi-item scales to the survey data. The fitness 
indexes are shown in Table 2. Six measurement models have outperformed or approached the following conventional standards after correlating error terms within some factors: the normed chisquare (the model chi-square divided by the degree of freedom) should be in the range of $1-5$, the Root Mean Square Error of Approximation (RMSEA) $\leq 0.06$, Tucker-Lewis Index (TLI) $\geq 0.95$, and Comparative Fit Index (CFI) $\geq 0.95$ (Byrne, 2010; Hu \& Bentler, 1999). The results also demonstrated that the China reputation scale measured four dimensions of China reputation reasonably well: emotional bond, advanced economy, social-cultural environment, and effective government. Therefore, we decided to retain all six measurement models for further statistical analyses.

Table 2. Fit indices for confirmatory factor analysis of six key constructs

\begin{tabular}{llllll}
\hline Construct & $\chi^{\mathbf{2}}(\mathbf{d f})$ & Normed $\chi^{\mathbf{2}}$ & RMSEA & TLI(NNFI) & CFI \\
\hline China Media Coverage & $37.13(24)^{*}$ & 1.55 & 0.038 & 0.978 & 0.985 \\
Experiences related to China & $5.97(2) \dagger$ & 2.99 & 0.073 & 0.932 & 0.977 \\
Subjective norm & $1.44(1)$ & 1.44 & 0.034 & 0.997 & 1.000 \\
China Reputation & $391.14(151)^{* *}$ & 2.59 & 0.065 & 0.892 & 0.914 \\
Studying in China attitudes & $.357(2)$ & .178 & 0.000 & 1.004 & 1.000 \\
Studying in China intent & $.026(1)$ & .026 & 0.000 & 1.007 & 1.000 \\
\hline
\end{tabular}

Note. RMSEA: root mean square error of approximation, TLI: the Tucker-Lewis index or NNFI: non-normed fit index, CFI: comparative fit index. $\dagger \mathrm{p}<.10 * \mathrm{p}<.05 . * * \mathrm{p}<.01$.

\section{Results}

The descriptive statistics of 374 respondents are reported in Table 3 . The majority of the sample is female $(66.3 \%)$, white $(85 \%)$, and young $(92.8 \%$ under 25$)$ (mean $=21.8$ and median $=$ 21). Their family annual income distribution is quite even under $\$ 100,000$, except that $24.1 \%$ of their families earn over $\$ 100,000$ annually. However, a big majority of their monthly personal income falls below $\$ 800(88.5 \%)$.

Table 3. Descriptive Statistics

\begin{tabular}{|c|c|c|c|c|c|c|c|c|}
\hline & \multicolumn{2}{|l|}{ Male } & \multicolumn{3}{|l|}{ Female } & Mean & SD & Median \\
\hline \multirow[t]{2}{*}{ Gender } & \multicolumn{2}{|l|}{$32.6 \%$} & $66.3 \%$ & \multicolumn{2}{|l|}{ Age } & 21.77 & 4.08 & 21 \\
\hline & White & Hispanics & American Indians & Asian & Black & \multicolumn{2}{|c|}{ Racially Mixed } & Other \\
\hline Race & $85 \%$ & $3.5 \%$ & $0.5 \%$ & $2.7 \%$ & $2.4 \%$ & $4.8 \%$ & & $1.1 \%$ \\
\hline \multicolumn{3}{|c|}{ Family Annual Income (SES) } & $\%$ & \multicolumn{3}{|c|}{ Personal Monthly Income } & \multicolumn{2}{|l|}{$\%$} \\
\hline \multicolumn{3}{|c|}{ Less than $\$ 30,000$} & $12 \%$ & \multicolumn{3}{|c|}{ Less than $\$ 200$} & \multicolumn{2}{|l|}{$41.4 \%$} \\
\hline \multicolumn{3}{|c|}{$\$ 30,001-\$ 40,000$} & $10.4 \%$ & \multicolumn{3}{|c|}{$\$ 201-\$ 400$} & \multicolumn{2}{|l|}{$28.4 \%$} \\
\hline \multicolumn{3}{|c|}{$\$ 40,001-\$ 50,000$} & $6.4 \%$ & \multicolumn{3}{|c|}{$\$ 401-\$ 600$} & \multicolumn{2}{|l|}{$11.2 \%$} \\
\hline \multicolumn{3}{|c|}{$\$ 50,001-\$ 60,000$} & $11 \%$ & \multicolumn{3}{|c|}{$\$ 601-\$ 800$} & \multicolumn{2}{|l|}{$7.5 \%$} \\
\hline \multicolumn{3}{|c|}{$\$ 60,001-\$ 70,000$} & $11 \%$ & \multicolumn{3}{|c|}{$\$ 801-\$ 1,000$} & \multicolumn{2}{|l|}{$6.4 \%$} \\
\hline \multicolumn{3}{|c|}{$\$ 70,001-\$ 80,000$} & $9.4 \%$ & \multicolumn{3}{|c|}{$\$ 1,001-\$ 1,200$} & \multicolumn{2}{|l|}{$2.1 \%$} \\
\hline \multicolumn{3}{|c|}{$\$ 80,001-\$ 90,000$} & $8.8 \%$ & \multicolumn{3}{|c|}{$\$ 1,201-\$ 1,400$} & \multicolumn{2}{|l|}{$1.1 \%$} \\
\hline \multicolumn{3}{|c|}{$\$ 90,001-\$ 100,000$} & $7.0 \%$ & \multicolumn{3}{|c|}{$\$ 1,401-\$ 1,600$} & \multicolumn{2}{|l|}{$0.3 \%$} \\
\hline \multicolumn{3}{|c|}{ More than $\$ 100,000$} & $24.1 \%$ & \multicolumn{3}{|c|}{ More than $\$ 1,600$} & \multicolumn{2}{|l|}{$1.6 \%$} \\
\hline
\end{tabular}

Note. $\mathrm{N}=374$.

Table 4 shows the means, standard deviations and independent samples t-test results by gender of key concepts. There was no significant difference in their exposure to media coverage on China, China experiences, subjective norm, and perceptions of China (China reputation) across gender. However, male respondents reported more favorable attitudes toward studying in China and 
stronger intent to study in China than females. Therefore, gender will be entered for further analyses as an important control variable.

Table 4. Means, standard deviations, and t-test results of key concepts

\begin{tabular}{|c|c|c|c|c|c|c|c|c|c|}
\hline Concept & Mean & SD & Skewness & Kurtosis & Male Mean & Female Mean & $\mathrm{t}$ & $\mathrm{df}$ & $\mathrm{p}$ \\
\hline $\begin{array}{l}\text { China Media } \\
\text { Coverage }\end{array}$ & 23.55 & 4.97 & .060 & .60 & 23.84 & 23.33 & .924 & 239 & .357 \\
\hline China Experiences & 7.93 & 2.69 & 1.32 & 2.95 & 7.87 & 7.94 & -.244 & 228 & .808 \\
\hline Subjective Norm & 19.70 & 6.60 & -.19 & -.16 & 20.36 & 19.44 & 1.227 & 219 & .221 \\
\hline China Reputation & 96.06 & 14.20 & -.04 & -.002 & 95.40 & 96.38 & -.631 & 242 & .529 \\
\hline $\begin{array}{l}\text { Studying in China } \\
\text { attitudes }\end{array}$ & 17.19 & 6.20 & -.16 & -.84 & 18.13 & 16.69 & $2.037^{*}$ & 217 & .043 \\
\hline $\begin{array}{l}\text { Studying in China } \\
\text { intent }\end{array}$ & 9.59 & 4.40 & 1.04 & 1.04 & 10.41 & 9.14 & $2.470^{*}$ & 198 & .014 \\
\hline
\end{tabular}

Note. SD = Standard Deviation. Total $\mathrm{N}=374$. Female $\mathrm{N}=248$. Male $\mathrm{N}=122$. Independent samples t-test by gender (equal variances not assumed). $* p<.05, * * p<.01,2$-tailed.

The maximum likelihood method of structural equation modeling was employed to fit the research model of Figure 1 to the survey data and test the hypotheses. Figure 2 displays the fitness indices of the revised model and the standardized path estimates of all variables after removing three dotted, insignificant paths. Compared with four cutoff criteria listed in the previous section (Byrne, 2010; Hu \& Bentler, 1999), the normed chi-square value and RMSEA of the revised model satisfied the requirements and the other two fitness indexes approached the standards closely: the normed $\chi^{2}=1.91$, RMSEA $=.049$, TLI $=.890$, and CFI $=.899$. We concluded that both models had achieved acceptable fit. As the revised model fit the survey data slightly better than the original model, it was retained for hypothesis testing and recommended for future research.

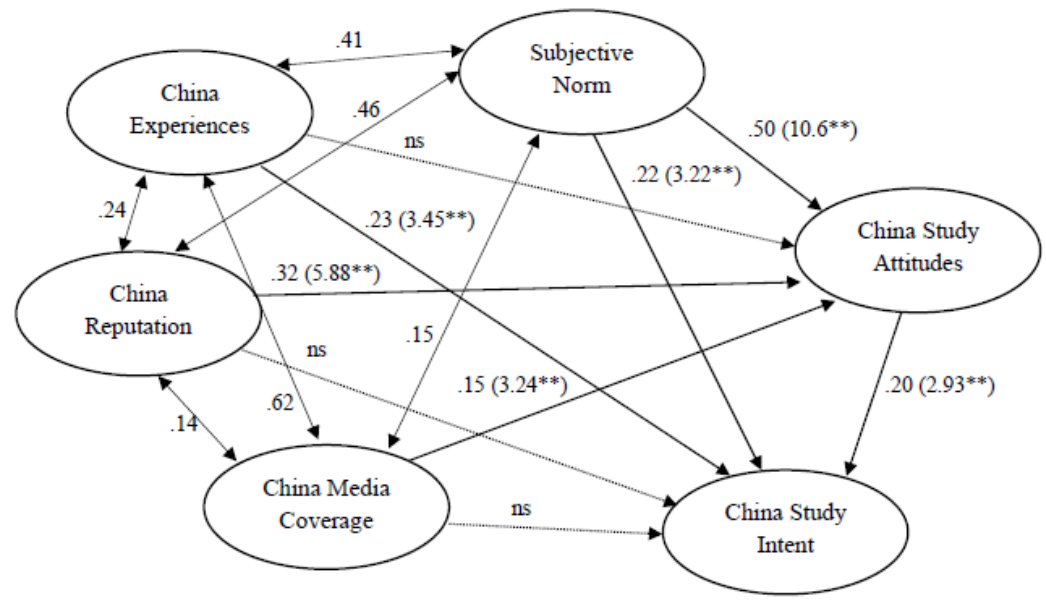

Figure 2. The Tested Model of Country Reputation and Studying Abroad with Standardized Path Estimates Note. $\mathbf{N}=374$. Significance of the path estimates is shown in parentheses (critical ratio). $\dagger p<.10, * p<.05, * * p<.01, \mathrm{~ns}=$ not significant. Model fit: $\chi^{2}=1817.86, d f=950, p=.000 ;$ RMSEA $=0.049$; TLI $=0.890 ;$ CFI $=0.899$. 
A hierarchical multiple regression modeling was also used to determine what demographic, psychological and behavioral factors predict US college students' perceptions of China (China's reputation), their attitudes toward and intent of studying in China. Three regression models were tested for each criterion variable by entering independent variables into three blocks (three steps). Nine model testing results are presented in Table 5. Only the results of the last three full regression models were used to test six hypotheses.

Table 5. Predictors of U.S. college students' perceptions of China, studying in China attitudes and intent

\begin{tabular}{|c|c|c|c|c|c|c|c|c|c|}
\hline \multirow[b]{3}{*}{ Gender $^{\mathrm{a}}$} & \multicolumn{3}{|c|}{ China Reputation } & \multicolumn{3}{|c|}{ Studying in China attitudes } & \multicolumn{3}{|c|}{ Studying in China intent } \\
\hline & & $\beta$ & & & $\beta$ & & & $\beta$ & \\
\hline & ns & $\mathrm{ns}$ & $.079 \dagger$ & $-.097 \dagger$ & ns & $-.064 \dagger$ & $-.114 *$ & $-.089 *$ & $-.076 \dagger$ \\
\hline Race $^{b}$ & ns & ns & ns & ns & $\mathrm{ns}$ & ns & ns & ns & $\mathrm{ns}$ \\
\hline Age & ns & ns & $-.096 \dagger$ & $.128 *$ & $\mathrm{~ns}$ & $.075 \dagger$ & ns & ns & ns \\
\hline Family income & ns & $-.120 *$ & $-.086 \dagger$ & ns & $-.095^{*}$ & $-.068 \dagger$ & ns & $-.078 \dagger$ & ns \\
\hline Personal income & ns & ns & ns & ns & ns & ns & ns & ns & ns \\
\hline $\begin{array}{l}\text { China media } \\
\text { coverage }\end{array}$ & & ns & ns & & $.103^{*}$ & $.085^{*}$ & & $\mathrm{~ns}$ & ns \\
\hline China experiences & & ns & ns & & $.077 \dagger$ & $.083 \dagger$ & & $.234 * * *$ & $.214 * * *$ \\
\hline Subjective norm & & $.413 * * *$ & $.188 * *$ & & $.626 * * *$ & $.532 * * *$ & & $.402 * * *$ & $.228 * * *$ \\
\hline $\begin{array}{l}\text { China reputation } \\
\text { Study in China } \\
\text { attitudes }\end{array}$ & - & - & $\overline{.348 * * *}$ & & & $.226 * * *$ & & & $\begin{array}{l}\mathrm{ns} \\
.270 * * *\end{array}$ \\
\hline $\begin{array}{l}\text { Study in China } \\
\text { intent }\end{array}$ & & & ns & & & - & & & \\
\hline Total $\mathrm{R}^{2}$ & .007 & $.178 * * * \mathrm{c}$ & $.243 * * * \mathrm{c}$ & .026 & $.473 * * * \mathrm{c}$ & $.515 * * * \mathrm{c}$ & .023 & $.312 * * * \mathrm{c}$ & $.352 * * * \mathrm{c}$ \\
\hline
\end{tabular}

\section{Discussions and Implications}

This pioneering study built and tested a conceptual model to examine whether and how U.S. college students' subjective norm, China experiences, exposure to media coverage of China, and their perceptions of China predicted their attitudes toward and intent of studying in China. We found that their subjective norm, China's reputation, and media coverage of China positively predicted their attitudes toward studying in China $\left(\mathrm{R}^{2}=51.5\right)$, whereas their intent to study in China $\left(\mathrm{R}^{2}=35.2\right)$ was determined by their attitudes, subjective norm, and China experiences. Their perceptions of China were significantly shaped by their attitudes toward studying in China and subjective norm. Their gender, age, and family income were marginally significant predictors of their attitudes toward studying in China but only their gender emerged to predict their intent negatively $(p$ $<$.10). These interesting findings carry important theoretical and practical implications for international education scholars, recruiters, communication specialists, administrators and even policy makers.

First of all, we discovered that the Theory of Planned Behavior can be applied to predict U.S. college students' attitudes toward and intent of studying in China as H1 and H2 were both strongly supported by our results. Our respondents' attitudes toward studying in China led to stronger intent to study in China. Their subjective norm turned out to be the most important predictor of their attitudes toward studying in China and the second most important predictor of their intent to study 
in China. These findings are consistent with previous studies on U.S. college students' intent and behavior of studying abroad (e.g., Fitzsimmons et al., 2013; Kang \& Megehee, 2014; Schnusenberg et al., 2012). Our findings highlighted the powerful influences of parents and friends on U.S. college students' decision-making process when it comes to studying in China. We believe that more U.S. college students will choose China as their destination for education abroad if their parents and friends think highly of cross-border education experiences in China and/or they are willing to support their decision to study in China morally and financially. It suggests that the marketing and promotional efforts of international education professionals will become more effective if they are targeting U.S. college students whose parents and/or friends had favorable opinions about China and studying in China.

Second, the present study shows that U.S. college students' direct and indirect experiences with China will motivate them to consider studying in China because H3b was firmly supported by the results in Table 5 and Figure 2. However, H3a was only marginally supported in Table 5 and not supported in Figure 2. Their direct and indirect experiences with China might have shaped their attitudes toward studying in China to some extent but the influence might have been mediated and mitigated by their friends' and parents' views. Our research results are generally consistent with previous studies that showed the influence of international travel and cross-border education on students' willingness to study abroad (e.g., Hackney et al., 2012; Lewis \& Niesenbaum, 2005; Owen et al., 2013; Pope et al., 2014). In addition, we provided some evidence that cultural exchange programs, sports event sponsorship, and interpersonal relationship building can help solidify U.S. college students' inclination to study in China. In this sense, our research findings validated the soft power of public diplomacy efforts over international education. Our study is one of the first studies to link public diplomacy efforts with study abroad intent in the context of U.S. college students and education abroad in China. This linkage is an interesting addition to the current research literature of public diplomacy and international education.

Our results show that China's country reputation had a direct effect on U.S. college students' attitudes toward studying in China with or without controlling demographics, whereas no direct effect of China's country reputation on U.S. college students' intent to study in China was detected in both the structural equation modeling and hierarchical regression modeling. Our SEM results also revealed an indirect effect of China's country reputation on U.S. college students' intent to study in China $(\beta=0.064, p<0.05)$. Thus, $\mathrm{H} 4 \mathrm{a}$ was firmly supported but $\mathrm{H} 4 \mathrm{~b}$ was rejected. The present study is probably one of the first studies that tested the direct and indirect effects of China's country reputation on U.S. college student's attitudes toward and intent of studying in China with structural equation modeling and hierarchical regression modeling. The current research sheds a new light on the role of country image (reputation) in the context of international education exchanges and cross-border education. The effects of country image or reputation or country of origins (COO) have been extensively researched by marketing scholars and detected in various product categories and services (Pharr, 2005; Bloemer et al., 2009). Nevertheless, limited studies focused on the influence of country image (reputation) on college students' decision to study abroad (e.g., Cubillo et al., 2006; Cubillo-Pinilla et al., 2009; Morrish \& Lee, 2011; Zatepilina-Monacell \& Kinsey, 2013). Our finding of the positive influence of China's reputation on U.S. college students' attitudes toward studying in China is consistent with these studies. It is a new finding regarding the indirect effect of China's country reputation on their intent to study in China. Overall, the empirical evidence points 
to the potential benefits of governmental and public diplomacy efforts to build China's reputation in Western developed countries such as the United States. A good country reputation of China will very likely foster U.S. College students' favorable attitudes toward studying in China. It may indirectly affect their intent to choose China as their study abroad destination, through their China experiences, families and friends. As it is a correlational study, the results also suggest that young Americans' perceptions of China are shaped by their families and friends directly. China's reputation can be strengthened by friendly cultural and educational exchanges including but not limited to tourism, study abroad, mission trips, and even business trips to China.

Additionally, we have uncovered little or weak effects of media coverage of China on U.S. college students' perceptions of China, their attitudes toward and intent of studying in China. Our respondents' reported exposure to media coverage of China failed to predict China's country reputation when demographics were controlled, although China media coverage and China's country reputation were positively correlated in our SEM model. Hence, H5 was not supported. China media coverage emerged as a significant predictor of U.S. college students' attitudes toward studying in China in both SEM modeling and hierarchical regression modeling, while having no effect on their intent to study in China in both models. Thus, H6a was supported and H6b was rejected. The fact that we could not find any media influence on our participants' perceptions of China speaks volumes about the diminishing role of mass/interactive media to shape U.S. citizens' overall impressions of foreign countries. U.S. citizens have become less reliant on traditional and new media to understand China. Besides, their trust and confidence in the mass media had dropped to $32 \%$, the lowest level in its polling history, according to Gallup (2016). As the world has become a global village, they have growing opportunities to personally experience China through travel, cultural exchanges, and interpersonal communications to form their independent opinions about China. On the other hand, the scant and infrequent coverage of China in traditional and new media is also the culprit. The mean score of our respondents' exposure to media coverage of China is 23.55 with a standard deviation of 4.97 , below the hypothetical score of 27 which they would get if they answered that they were sometimes exposed to media coverage of China in nine media classes/vehicles. Further research is needed to find whether the media effect on their perceived China reputation will become significant, given the increased media coverage of China in a special time period such as the Beijing Winter Olympics 2022. The weak media influence on U.S. college students' attitudes toward studying in China might become stronger when China has suddenly become the center of U.S. traditional and new media attention. Based on our empirical research findings, we continue to encourage the Chinese government and non-governmental organizations to improve their relations with U.S. traditional and new media establishment to earn favorable coverage of China and news events in China. To reach U.S. youths, they should also consider securing paid and earned positive portrayals of China and Chinese universities on social media sites such as Facebook, Twitter, Instagram, Snapchat, LinkedIn, Pinterest, Tumblr and Google+.

Finally, we have to acknowledge a few limitations of this study. Our findings can only be generalized to similar medium-size and big public universities in the United States. Future researchers should employ a large national representative sample to generalize their findings to the population of U.S. college students. A mixed method approach is also suggested to provide deep insights into U.S. college students' perceptions of China, Chinese universities, study abroad 
motivations, attitudes, and intent. Other important predictors should also be included in further studies such as language barriers, costs, and cultural (dis)similarities.

\section{References}

Allen, H. W., \& Dupuy, B. (2012). Study abroad, foreign language use, and the communities standard. Foreign Language Annals, 45(4), 468-493.

Altbach, P. G. (2004). Higher education crosses borders: Can the United States remain the top destination for foreign students? Change: The Magazine of Higher Learning, 36(2), 18-25.

Ajzen, I. (1991). The theory of planned behavior. Organizational Behavior and Human Decision Processes, 50, 179-211.

American Council on Education (ACE), Art \& Science Group LLC, and the College Board,

(2008). College-bound students' interests in study abroad and other international learning activities. Retrieved from https://www.acenet.edu/news-room/Documents/2008-Student-Poll.pdf

American Institute for Foreign Study (AIFS) (2013). AIFS study abroad outcomes: A view from our alumni 1990-2010. Retrieved from http://www.aifsabroad.com/advisors/pdf/AIFS_Study_Abroad_Outcomes.pdf

Armitage, C. J., \& Conner, M. (2001). Efficacy of the theory of planned behaviour: A meta-analytic review. British Journal of Social Psychology, 40(4), 471-499.

Anholt, S. (2015). Public diplomacy and competitive identity: Where's the link? In G. J. Golan, S.-U. Yang, and D. F. Kinsey (eds), International public relations and public diplomacy: Communication and engagement. New York : Peter Lang, pp. 189-207.

Anholt, S. (2009). The media and national image. Place Branding and Public Diplomacy, 5(3), 169-179.

Association of American Colleges and Universities (AAC\&U). (2010). Raising the bar: Employer's views on college learning in the wake of the economic downturn. Retrieved from https://www.aacu.org/sites/default/files/files/LEAP/2009_EmployerSurvey.pdf

Bai, J., Larimer, S., \& Riner, M. B. (2016). Cross-Cultural pedagogy: Practical strategies for a successful interprofessional study abroad course. Journal of the Scholarship of Teaching and Learning, 16(3), 72-81.

Bennett, W. L., \& Paletz, D. L. (Eds.) (1994). Taken by Storm: The Media, Public Opinion, and US Foreign Policy in the Gulf War. University of Chicago Press.

Bian, C. (2013). Study abroad as self-development: An analysis of international students' experience in China and France. Frontiers of Education in China, 8(3), 448-477.

Black, H. T., \& Duhon, D. L. (2006). Assessing the impact of business study abroad programs on cultural awareness and personal development. Journal of Education for Business, 81(3), 140-144.

Bloemer, J., Brijs, K., \& Kasper, H. (2009). The CoO-ELM model: A theoretical framework for the cognitive processes underlying country of origin-effects. European Journal of Marketing, 43(1/2), 62-89.

Byrne, B. M. (2010). Structural equation modeling with AMOS: Basic concepts, applications, and programming. New York: Routledge.

Braskamp, L. A., Braskamp, D. C., \& Merrill, K. C. (2009). Assessing progress in global learning and development of students with education abroad experiences. Frontiers: The Interdisciplinary Journal of Study Abroad, 18, 101-118.

Brux, J., M. \& Fry, B. (2010). Multicultural students in study abroad: Their interests, their issues, and their constraints. Journal of Studies in International Education, 14(5), 508-527.

Cai, W., \& Sankaran, G. (2015). Promoting critical thinking through an interdisciplinary abroad program. Journal of International Students, 5(1), 38-49.

Chen, D. (2008). A social distance study of American participants in a China study abroad program. USChina Education Review, 5 (9), 17-22. 
Chen, T.-P. (2014). Only $1 \%$ of U.S. and U.K. study-abroad students interested in China. The Wall Street Journal. Retrieved from http://blogs.wsj.com/chinarealtime/2014/04/28/only-1-of-u-s-and-u-k-studyabroad-students-interested-in-china/

Cho, J., \& Morris, M. W. (2015). Cultural study and problem-solving gains: Effects of study abroad, openness, and choice. Journal of Organizational Behavior, 36(7), 944-966.

Core, R. S. (2017). Assessing global learning in short-term study abroad: Population, environment, and society in Shanghai. Teaching Sociology, 45(4), 399-408.

Costello, A. B. \& Osborne, J. W. (2005). Best practices in exploratory factor analysis: Four recommendations for getting the most from your analysis. Practical Assessment, Research \& Evaluation, 10(7), retrieved from http://pareonline.net/pdf/v10n7.pdf

Cubillo, J.M., Sanchez, J., \& Cervino, J. (2006). International students' decision-making process. Journal of Education Management, 20(2), 101-115.

Cubillo-Pinilla, J. M., Zuñiga, J., Losantos, I. S., \& Sánchez, J. (2009). Factors influencing international students' evaluations of higher education programs. The Journal of American Academy of Business, Cambridge, 15(1), 270-278.

Deans, P. C. (2011). A framework, learning outcomes and lessons learned for an undergraduate short-term study abroad in China. Journal of Teaching in International Business, 22(3), 193-216.

DeGraaf, D., Slagter, C., Larsen, K., \& Ditta, E. (2013). The long-term personal and professional impacts of participating in a study abroad program. Frontiers: The Interdisciplinary Journal of Study Abroad, $23,42-59$.

Deviney, D., Vrba, T., Mills, L., \& Ball, E. (2014). Why some students study abroad and others stay. Research in Higher Education Journal, 25, 1-14.

Diao, W. (2016). Peer socialization into gendered L2 Mandarin practices in a study abroad context: Talk in the dorm. Applied Linguistics, 37(5), 599-620

Dillman, D. A. (2007), Mail and internet surveys: The tailored design method, Hoboken, N.J: Wiley.

Ding, X. (2016). Exploring the experiences of international students in China. Journal of Studies in International Education, 20(4), 319-338.

Dixon, B. (2013). Education abroad in China: Literature review of study abroad program types, outcomes and benefits. Frontiers: The Interdisciplinary Journal of Study Abroad, 23, 105-122.

Dolby, N. (2004). Encountering an American self: Study abroad and national identity.

Comparative Education Review, 48(2), 150-173.

Dolby, N. (2007). Reflections on nation: American undergraduates and education abroad.

Journal of Studies in International Education, 11(2), 141-156.

$\mathrm{Du}, \mathrm{H}$. (2013). The development of Chinese fluency during study abroad in China. Modern Language Journal, 97(1), 131-143.

$\mathrm{Du}$, H. (2015). American college students studying abroad in China: Language, identity, and selfpresentation. Foreign Language Annals, 48(2), 250-266.

Duperron, L., \& Overstreet, M. H. (2009). Preparedness for study abroad: The linguistic outcomes of a short-term Spanish program by third, fourth and sixth semester L2 learners. Frontiers: The Interdisciplinary Journal to Study Abroad, 18, 157-179.

English, A. S., Allison, J., \& Ma, J. H. (2016). Understanding Western students: Motivations and benefits for studying in China. Journal of Education and Training Studies, 4(8), 44-55.

Fang, B. (2015). On changing trends of China's education of ASEAN students in the past 15 years - an analysis of the related statistical data of 1999-2013. Comparative Education Review, 310, 77-86. [In Chinese]

Finney, T. G., \& Finney, R. Z. (2010). Are students their universities' customers? An exploratory study. Education + Training, 52(4), 276-291.

Fitzsimmons, S., Flanagan, D., \& Wang, X. (2013). Business students' choice of short-term or long-term study abroad opportunities. Journal of Teaching in International Business, 24(2), 125-137.

Fornell, C., \& Larcker, D. F. (1981). Evaluating structural equation models with unobservable variables and measurement error. Journal of Marketing Research, 18(1), 39-50. 
Fornerino, M., Jolibert, A., Sánchez, C. M., \& Zhang, M. (2011). Do values or goals better explain intent? A cross-national comparison. Journal of Business Research, 64, 490-496.

Foster, P. B. (2001). A language and cultural practicum course in Nanjing: Maximizing the Student's use of Chinese. Frontiers: The Interdisciplinary Journal of Study Abroad, 7, 121-128

Franklin, K. (2010). Long-term career impact and professional applicability of the study abroad experience. Frontiers: The Interdisciplinary Journal of Study Abroad, 19, 169-190.

Fullerton, J. A., Kendrick, A., Chan, K., Hamilton, M., \& Kerr, G. (2007). Attitudes towards American brands and Brand America. Place Branding and Public Diplomacy, 3(3), 205-212.

Gallup (2016). Americans' trust in mass media sinks to new low. Retrieved from http://www.gallup.com/poll/195542/americans-trust-mass-media-sinks-new-low.aspx

Gary, K. S., Murdock, G. K., \& Stebbins, C. D. (2002). Assessing study abroad's effect on an

international mission. Change, 34(3), 44-51.

Geelhoed, R., Abe, J., \& Talbot, D. (2003). A qualitative investigation of US students'

experiences in an international peer program. Journal of College Student Development, 44, 5-17.

Gerbner, G., \& Gross, L. (1976). The scary world of TV's heavy viewer. Psychology Today, 9, 41-45, 89.

Gertner, R. (2011). The impact of country attributes on study abroad programs and tourism destination purchasing decisions. Review of Business Research, 11(1), 34-45.

Golan, G. J. (2006). Inter-media agenda setting and global news coverage: Assessing the influence of The New York Times on three network television evening news programs. Journalism Studies, 7(2), 323333.

Golan, G. J. (2014). An integrated approach to public diplomacy. In G. J. Golan, S.-U. Yang, and D. F. Kinsey (eds.), International public relations and public diplomacy: Communication and engagement. New York : Peter Lang, pp. 417-440.

Goldoni, F. (2015). Preparing students for studying abroad. Journal of the Scholarship Of Teaching \& Learning, 15(4), 1-21.

Goldstein, S. B., \& Kim, R. I. (2006). Predictors of US college students' participation in study abroad programs: A longitudinal study. International Journal of Intercultural Relations, 30, 507-521.

Gordon, P. J., Patterson, T., \& Cherry, J. (2014). Increasing international study abroad rates for business students. Academy of Educational Leadership Journal, 18(3), 77-86.

Hackney, K., Boggs, D., \& Borozan, A. (2012). An empirical study of student willingness to study abroad. Journal of Teaching in International Business, 23(2), 123-144.

Hansel, B. (2008). AFS long term impact study. Report 2: Looking at intercultural sensitivity, anxiety, and experience with other cultures. New York: AFS International.

Harris, R. J., \& Karafa, J. A. (1999). A cultivation theory perspective of worldwide national impressions of the United States. In Y. R. Kamalipour (ed.) Images of the U.S. Around the World: A Multicultural Perspective (pp. 3-18). Albany: State University of New York Press.

He, Y., \& Qin, X. (2017). Students' perceptions of an internship experience in China: A pilot study. Foreign Language Annals, 50(1), 57-70

Heslop, L., Nadeau, J., \& O'Reilly, N. (2010). China and the Olympics: views of insiders and outsiders. International Marketing Review, 27(4), 404-433.

Hoffa, W., \& DePaul, S. C. (Eds.) (2010). A history of U.S. study abroad: 1965-present. Lancaster, PA: Frontiers: The Interdisciplinary Journal of Study Abroad.

Hu, L., \& Bentler, P. M. (1999). Cutoff criteria for fit indexes in covariance structure analysis: Conventional criteria versus new alternatives. Structural Equation Modeling, 6 (1), 1-55.

Im, H. H., \& Chon, K. (2008). An exploratory study of movie-induced tourism: A case of the movie The Sound of Music and its locations in Salzburg, Austria. Journal of Travel \& Tourism Marketing, 24(2/3), 229-238.

Institute of International Education (IIE) (2017). Top 25 destinations of U.S. study abroad students, 2014/15 - 2015/16. Open Doors Report on International Educational Exchange. Retrieved from http://www.iie.org/opendoors 
Iwashita, C. (2008). Roles of films and television dramas in international tourism: The case of Japanese tourists to the UK. Journal of Travel \& Tourism Marketing, 24(2/3), 139-151.

Jiani, M. A. (2017). Why and how international students choose Mainland China as a higher education study abroad destination. Higher Education, 74(4), 563-579.

Jochum, C. J. (2014). Measuring the effects of a semester abroad on students' oral proficiency gains: A comparison of at-home and study abroad. Frontiers: The Interdisciplinary Journal of Study Abroad, 24, 93-104.

Jue, S. (September 20, 2010). A New Public Diplomacy Initiative: Sending 100,000 American Students to China. American Diplomacy, 1-7.

Kang, B., \& Megehee, C. M. (2014). Advancing facilitators and deterrents theory of students' studyabroad decisions. Review of Higher Education \& Self-Learning, 7(24), 124-140.

Kuzma, A., Kuzma, J., \& Thiewes, H. (2012). Contrasting student attitudes toward study abroad programs among college of business majors. American Journal of Business Education, 5(4), 457-464.

Lala, V., Allred, A. T., \& Chakraborty, G. (2009). A multidimensional scale for measuring country image. Journal of International Consumer Marketing, 21(1), 51-66.

Lee, C. S., Therriault, D. J., \& Linderholm, T. (2012). On the cognitive benefits of cultural experience: Exploring the relationship between studying abroad and creative thinking. Applied Cognitive Psychology, 26(5), 768-778.

Lewis, T. L., \& Niesenbaum, R. A. (2005). Extending the stay: Using community based research and service learning to enhance short-term study abroad. Journal of Studies in International Education, 9 (3) 251-264.

Li, J., Guo, F., \& You, Y. (2017). Study abroad during college: Comparison between China and the United States. Current Issues in Comparative Education, 19(2), 111-139.

Li, M. (2011). Rising from Within: China's Search for a Multilateral World and Its Implications for SinoUS Relations. Global Governance, 17(3), 331-351.

$\mathrm{Li}$, X. (2015). International students in China: Cross-cultural interaction, integration, and identity construction. Journal of Language, Identity \& Education, 14(4), 237-254.

$\mathrm{Li}$, X. (2017). An analysis on the motivations of foreign students studying in China - Based on the case of Korean Students. Journal of Jiangsu Normal University, 2, 10-16. [In Chinese]

Lin, W. (2013). Factors affecting high-involvement product purchasing behavior. Quality \& Quantity, 47(6), 3113-3133.

Little, R. J. A. (1992). Regression with missing X's: A review. Journal of the American Statistical Association, 87, 1227-1237.

Liu, J. J. (2010). Assessing Students' Language Proficiency: A New Model of Study Abroad

Program in China. Journal of Studies in International Education, 14(5), 528-544.

Liu, X. (2014). Comparison on the Developmental Trends between Chinese Students Studying Abroad and Foreign Students Studying in China. Journal of International Students, 4(1), 34-47.

Liu, Y., Wang, H., \& Hung, F.-S. (2013). Why do foreign students choose to study in China -An empirical analysis based on the survey data from Beijing universities. Journal of Higher Education, 5, 32-38, 52. [In Chinese]

Lumkes, J. J., Hallett, S., \& Vallade, L. (2012). Hearing versus experiencing: The impact of a short-term study abroad experience in China on students' perceptions regarding globalization and cultural awareness. International Journal of Intercultural Relations, 36(1), 151-159

Luo, J., \& Jamieson-Drake, D. (2015). Predictors of study abroad intent, participation, and college outcomes. Research in Higher Education, 56(1), 29-56.

Manzenreiter, W. (2010). The Beijing Games in the Western Imagination of China: The weak power of soft power. Journal of Sport \& Social Issues, 34(1), 29-48.

Matthews, P. R., Hameister, B. G., \& Hosley, N. S. (1998). Attitudes of college students toward study abroad: Implications for disability service providers. Journal of Postsecondary Education and Disability, 13(2), 67-77. 
Mazzarol, T., \& Soutar, G. N. (2002). "Push-pull" factors influencing international student destination choice. International Journal of Educational Management, 16(2), 82-90.

Meijer, H. (2015). Actors, coalitions, and the making of foreign security policy: US strategic trade with the People's Republic of China. International Relations of the Asia-Pacific, 15(3), 433-475.

Ministry of Education of the People's Republic of China (MOE) (2012). Plan for Study in China. Retrieved from www.csc.edu.cn/studyinchina/newsdetailen.aspx?cid=192\&id=1348

Ministry of Education of the People's Republic of China (MOE) (2017). Brief statistics of international students in China in $2016 . \quad$ Retrieved from www.moe.edu.cn/jyb_xwfb/xw_fbh/moe_2069/xwfbh_2017n/xwfb_170301/170301_sjtj/20 1703/t20170301_297677.html [In Chinese]

Mitchell, H., \& Stewart, M. (2012). Movies and holidays: the empirical relationship between movies and tourism. Applied Economics Letters, 19(15), 1437-1440.

Morrish, S. C., \& Lee, C. (2011). Country of origin as a source of sustainable competitive advantage: The case for international higher education institutions in New Zealand. Journal of Strategic Marketing, 19(6), 517-529.

Morrison, W. M. (2015). China's economic rise: History, trends, challenges, and implications for the United States. Congressional Research Service, Washington, D.C. Retrieved from https://www.fas.org/sgp/crs/row/RL33534.pdf

Movassaghi, H., Unsal, F., \& Göçer, K. (2014). Study abroad decisions: Determinants \& perceived consequences. Journal of Higher Education Theory \& Practice, 14(1), 69-80.

Murphy, D., Sahakyan, N., Doua, Y., \& Magnan, S. S. (2014). The impact of study abroad on the global engagement of university graduates. Frontiers: The Interdisciplinary Journal of Study Abroad, 24, 124.

Mulvaney, M. K. (2017). The long-term impact of study abroad on honors program alumni. Frontiers: The Interdisciplinary Journal of Study Abroad, 29(1), 46-67.

Nesdale, D., \& Todd, P. (1993). Internationalizing Australian universities: The intercultural

contact issue. Journal of Tertiary Education Administration, 15, 189-202.

Nguyen, S. (2014). ' $F$ ' is for family, friend and faculty influences: Examining the communicated messages about study abroad at a Hispanic-serving institution (HIS). International Education, 43(2), 77-93.

Nyaupane, G. P., Paris, C. M., \& Teye, V. (2011). Study abroad motivations, destination selection and pretrip attitude formation. International Journal of Tourism Research, 13(3), 205-217.

Nunnally, J. C., \& Bernstein, I. H. (1994). Psychometric theory. New York, NY: McGraw-Hill, Inc.

Obermiller, C., Fleenor, P., \& Raven, P. (2005). Students as customers or products: Perceptions of faculty and students. Marketing Education Review, 15(2), 27-36.

Oh, J. S. (2012). Business Interests and US-China Relations on Climate Change. Pacific Focus, 27(1), 3661.

Owen, C., Breheny, P., Ingram, R., Pfeifle, W., Cain, J., \& Ryan, M. m. (2013). Factors associated with pharmacy student interest in international study. American Journal of Pharmaceutical Education, 77(3), 1-10.

Paige, R. M., Fry, G. W., Stallman, E. M., Josic, J., \& Jon, J. E. (2009). Study abroad for global engagement: The long-term impact of mobility experiences. Intercultural Education, 20(S1-2), S2944.

Parameswaran, R., \& Pisharodi, R. (2002). Assimilation effects in country image research. International Marketing Review, 19(2/3), 259-278.

Passow, T., Fehlman, R., \& Grahlow, H. (2005). Country reputation-from measurement to management: The case of Liechtenstein. Corporate Reputation Review, 7(4), 309-326.

Pavlou, P. A., \& Fygenson, M. (2006). Understanding and prediction electronic commerce adoption: An extension of the theory of planned behavior. MIS Quarterly, 30(1), 115-143. 
Pedersen, P. J. (2010). Assessing intercultural effectiveness outcomes in a year-long study abroad program. International Journal of Intercultural Relations, 34(1), 70-80.

Pereira, A., Hsu, C.-C., \& Kundu, S. K. (2005). Country-of-origin image: measurement and cross-national testing. Journal of Business Research, 58(1), 103-106.

Pharr, J. M. (2005). Synthesizing country-of-origin research from the last decade: Is the concept still salient in an era of global brands? Journal of Marketing Theory \& Practice, 13(4), 34-45.

Ponzi, L. J., Fombrun, C. J., \& Gardberg, N. A. (2011). RepTrak Pulse: Conceptualizing and validating short-term measure of corporate reputation. Corporate Reputation Review, 14(1), 15-35.

Pope, J. A., Sánchez, C. M., Lehnert, K., \& Schmid, A. S. (2014). Why do Gen Y students study abroad? Individual growth and the intent to study Abroad. Journal of Teaching in International Business, 25(2), 97-118.

Posey, J. T. Jr. (2003). Study abroad: Educational and employment outcomes of participants

versus nonparticipants (Ph.D. dissertation). Florida State University.

Presley, A., Damron-Martínez, D., \& Zhang L. (2010). A study of business student choice to study abroad: A test of the theory of planned behavior. Journal of Teaching in International Business, 21(4), 227247.

Randolph, O., Fullerton, J., \& Kendrick, A. (2010). International attitudes toward America. Place Branding \& Public Diplomacy, 6(3), 244-255.

Reputation Institute, the. (2012). 2012 Country RepTrak ${ }^{\mathrm{TM}}$ Topline Report. Retrieved from http://www.tfsa.ca/storage/reports/2012_Country_RepTrak_Topline_Report.pdf

Rexeisen, R. J., Anderson, P. H., Lawton, L., \& Hubbard, A. C. (2008). Study abroad and intercultural development: A longitudinal study. Frontiers: The Interdisciplinary Journal to Study Abroad, 17, 120.

Riggan, J., Gwak, S., Lesnick, J., Jackson, K., \& Olitsky, S. (2011). Meta-Travel: A Critical Inquiry into a China Study Tour. Frontiers: The Interdisciplinary Journal of Study Abroad, 21, 236-253.

Rivas, C. V. (2011). The rise and fall of Mexico's international image: Stereotypical identities, media strategies and diplomacy dilemmas. Place Branding \& Public Diplomacy, 7(1), 23-31.

Rojas-Méndez, J. (2013). The nation brand molecule. Journal of Product \& Brand Management, 22(7), 462-472.

Ryan, M. E., \& Twibell, R. S. (2000). Concerns, values, stress, coping, health, and educational outcomes of college students who studied abroad. International Journal of Intercultural Relations, 24(4), 409435.

Salisbury, M., Paulsen, M., and Pascarella, E. T. (2010). To see the world or stay at home: Applying an integrated student choice model to explore the gender gap in the intent to study abroad. Research in Higher Education, 51(7), 615-640.

Salisbury, M. H., Paulsen, M. B., and Pascarella, E. T. (2011). Why do all the study abroad students look alike? Using an integrated student choice model to explore differences in the development of white and minority students' intent to study abroad. Research in Higher Education, 52(2), 123-150.

Salisbury, M. H., Umbach, P. D., Paulsen, M. B., and Pascarella, E. T. (2009). Going global: Understanding the choice process of the intent to study abroad. Research in Higher Education, 50(2), 119-143.

Salyers, V., Carston, C., Dean, Y., \& London, C. (2015). Exploring the motivations, expectations, and experiences of students who study in global settings. Journal of International Students, 5(4), 368382.

Saunders, P. C. (2014). China's rising power, the U.S. rebalance to Asia, and implications for U.S.-China Relations. Issues \& Studies, 50(3), 19-55.

Schnusenberg, O., de Jong, P., \& Goel, L. (2012). Predicting study abroad intentions based on the theory of planned behavior. Decision Sciences Journal of Innovative Education, 10(3), 337-361.

Shambaugh, D. (2015). China's Soft-Power Push: The Search for Respect. Foreign Affairs, 94 (4), 99107. 
Shirley, S. W. (2006). The gender gap in post-secondary study abroad: Understanding and marketing to male students (Doctoral dissertation, The University of North Dakota). Retrieved from http://www.aifsabroad.com/advisors/pdf/Gender_Gap_Shirley.pdf

Shrum, L. J., O'Guinn, T. C., Semenik, R. J., Faber, R. J. (1991). Process and effects in the construction of normative consumer beliefs: The role of television. Advances in Consumer Research, 18, 755-763.

Siow, M. (2015). China seeks to brush up on global image. Channel News Asia, March 31. Retrieved from http://www.channelnewsasia.com/news/asiapacific/china-seeks-to-brushup/1758222.html.

Song, H. S., \& Liu, L. (2014). Why do foreign students choose to study in China: An empirical study based on the gravity model. Journal of Higher Education, 35(11), 31-38. [In Chinese]

Song, Y.-A., \& Sung, Y. (2013). Antecedents of Nation Brand Personality. Corporate Reputation Review, $16(1), 80-94$.

Srikatanyoo, N., \& Gnoth, J. (2002). Country image and international tertiary education. Journal of Brand Management, 10(2), 139-146.

Stallman, E., Woodruff, G. A., Kasravi, J., and Comp, D. (2010). The diversification of the student profile. In W. W. Hoffa and S. C. DePaul (Eds.). A history of U.S. study abroad: 1965-present. (pp. 115160). Lancaster, PA: Frontiers: The Interdisciplinary Journal of Study Abroad.

Stemler, S.E. (2012). What should university admissions tests predict? Educational Psychologist, 4l(1), 5-17.

Stemler, S. E., Imada, T., \& Sorkin, C. (2014). Development and validation of the Wesleyan Intercultural Competence Scale (WICS): A tool for measuring the impact of study abroad experiences. Frontiers: The Interdisciplinary Journal of Study Abroad, 24, 25-58.

Tang, Z., Luo, J., \& Xiao, J. (2011). Antecedents of intention to purchase mass customized products. Journal of Product \& Brand Management, 20(4), 316-326.

Terry, D. J., \& Hogg, M. A. (1996). Group norms and the attitude-behavior relationship: A role for group identification. Personality and Social Psychology Bulletin, 8, 776-793.

The 100,000 Strong Foundation (2015). About us. Retrieved from http://100kstrong.org/about-us/

Toncar, M., Reid, J., \& Anderson, C. (2005). Perceptions and preferences of study abroad: Do business students have different needs? Journal of Teaching in International Business, 17(1/2), 61-80.

Twombly, S., Salisbury, M., Tumanut, S., \& Klute, P. (2012). Special issue: Study abroad in a new global century - renewing the promise, refining the purpose. ASHE Higher Education Report, 38(4), 1-152.

U.S. Census Bureau (2016). Top Trading Partners December 2016. Retrieved from https://www.census.gov/foreign-trade/statistics/highlights/top/top1612yr.html

Valenzuela, S., Park, N., \& Kee, K. F. (2009). Is there social capital in a social network site?: Facebook use and college students' life satisfaction, trust, and participation. Journal of Computer-Mediated Communication, 14 (4), 875-901.

van Veen, F., Göritz, A. S., \& Sattler, S. (2016). Response effects of prenotification, prepaid cash, prepaid vouchers, and postpaid vouchers: An experimental comparison. Social Science Computer Review, 34(3), 333-346.

Vande Berg, M. (2007). Intervening in the learning of US students abroad. Journal of Studies in

International Education, 11(3/4), 392-399.

Wang, J. (2011). Soft Power in China: Public Diplomacy through Communication. New York: Palgrave Macmillan.

Wang, X., \& Shoemaker, P. K. (2011). What shapes Americans' opinion of China? Country characters, public relations and mass media. Chinese Journal of Communication, 41(1), 1-20.

Watjatrakul, B. (2010). Using the student-as-customer concept in technology disciplines: Students' perspectives. International Journal of Behavioral, Cognitive, Educational and Psychological Sciences, 2(1), 1-5. 
Weigel, F. K., Hazen, B. T., Cegielski, C. G., \& Hall, D. J. (2014). Diffusion of innovations and the theory of planned behavior in information systems research: A meta-analysis. Communications of the Association for Information Systems, 34, 619-636.

Wen, W., Chen, L., Bai, Y., \& Cao, H. (2013). A comparative study of international students' experiences and satisfaction in Beijing. Social Sciences of Beijing, 2, 63-70. [In Chinese]

Williams, T. R. (2005). Exploring the impact of study abroad on students' intercultural communication skills: Adaptability and sensitivity. Journal of Studies in International Education, 9, 356-371.

Wynveen, C. J., Kyle, G. T., \& Tarrant, M. A. (2012). Study abroad experiences and global citizenship: Fostering proenvironmental behavior. Journal of Studies in International Education, 6(4), 334-352.

Yang, H. (2013). Bon appétit for apps: Young American consumers' acceptance of mobile applications. Journal of Computer Information Systems, 53(3), 85-96.

Yang, H., \& Wang, Y. (2017). The Influence of US Media and Country Image on Chinese High School Students' Attitudes toward and Intent of Studying in the USA. Journal of China Marketing, 6(2), 145-182.

Yang, L. L. (2016). Reasons for American John to come to China: A narrative study. Education Research Monthly, 2, 74-81. [In Chinese]

Yang, S. U., Shin, H., Lee, J. H., \& Wrigley, B. (2008). Country reputation in multidimensions: Predictors, effects, and communication channels. Journal of Public Relations Research, 20(4), 421440.

Zatepilina-Monacell, O., \& Kinsey, D.F. (2013). Media coverage and decision-making on the likelihood of studying in Mexico. Paper presented at the Association for Education in Journalism and Mass Communication's Mid-Winter Conference, International Communication Division, Norman, OK.

Zhang, C., \& Meadows III, C. W. (2012). International coverage, foreign policy, and national image: Exploring the complexities of media coverage, public opinion, and presidential agenda. International Journal of Communication, 6, 76-95.

Zhao, Y. (2014). Toward internal harmony: The role of Confucius Institutes in China's soft power. China Media Research, 10(1), 22-28. 


\section{Appendix A. Major Measures of the Survey on Studying in China}

\begin{tabular}{|c|c|}
\hline $\begin{array}{l}\text { Media Coverage on } \\
\text { China }^{1}\end{array}$ & $\begin{array}{l}\text { Please tell us how often you come across media coverage regarding China such as news, } \\
\text { analysis/commentary, consumer information, literature, sports or entertainment: } \\
\text { (1) Never. (2) Seldom. (3) Sometimes. (4) Often. (5) All the time. } \\
\text { 1.I have been exposed to TV programs about China. } \\
\text { 2.I have been exposed to radio programs about China. } \\
\text { 3.I have been exposed to the content about China on non-social media websites (including } \\
\text { mobile websites) such as Google, Yahoo, Time, the New York Times etc. } \\
\text { 4.I am exposed to the content about China on social media websites (including social media } \\
\text { apps) such as Facebook, Twitter, YouTube, Tumblr, Buzzfeed etc. } \\
\text { 5.I have been exposed to the content about China in movies. } \\
\text { 6.I have been exposed to the stories about China in print newspapers. } \\
\text { 7.I have been exposed to the stories about China in print magazines. } \\
\text { 8.I have been exposed to advertisements about China and/or Chinese companies and/or } \\
\text { products. } \\
\text { 9.I have been exposed to the stories about China in books. }\end{array}$ \\
\hline $\begin{array}{l}\text { Perceptions of } \\
\text { China/China } \\
\text { Reputation }^{2}\end{array}$ & $\begin{array}{l}\text { Please tell us to what extent you agree with the following statements regarding China: } \\
\text { (1) Strongly disagree. (2) Disagree. ( } 3 \text { ) Somewhat disagree. (4) Neither agree nor disagree. } \\
\text { (5) Somewhat agree. (6) Agree. (7) Strongly agree } \\
\text { 1. I have a good feeling about China. } \\
\text { 2. I respect China. } \\
\text { 3. I admire China. } \\
\text { 4. I trust China. } \\
\text { 5. China produces high quality products and services. } \\
\text { 6. China has many well-known brands. } \\
\text { 7. China is an important contributor to global economy. } \\
\text { 8. China is technologically advanced. } \\
\text { 9. China has a well-educated and reliable workforce. } \\
\text { 10. China has a good infrastructure such as roads, buildings, and telecommunications. } \\
\text { 11. China values education. } \\
\text { 12. China is a beautiful country. } \\
\text { 13. China has a rich historical past. } \\
\text { 14. China has a distinct culture. } \\
\text { 15. Chinese people are friendly and welcoming. } \\
\text { 16. China offers a favorable environment for doing business. } \\
\text { 17. China is run by an effective government. } \\
\text { 18. China has adopted progressive social and economic policies. } \\
\text { 19. China is a responsible participant in the global community. } \\
\text { 20. China is a safe place to live and travel. }\end{array}$ \\
\hline $\begin{array}{l}\text { Experiences related } \\
\text { to } \mathrm{China}^{3}\end{array}$ & $\begin{array}{l}\text { Please tell us about the direct and indirect personal experiences related to China you have had } \\
\text { in the following categories: } \\
\text { (1) None. (2) A little. (3) Some. (4) Considerable. (5) A lot. } \\
\text { 1.Traveled to/visited China. } \\
\text { 2.Used products or services manufactured in China. (Omitted) } \\
\text { 3.Participated in cultural events related to China such as Chinese New Year celebrations. } \\
\text { 4.Attended/Watched sporting events related to China such as Beijing } 2008 \text { Olympic Games. } \\
\text { 5.Heard about China from family members or friends. }\end{array}$ \\
\hline
\end{tabular}




\begin{tabular}{|c|c|}
\hline Subjective Norm ${ }^{5}$ & $\begin{array}{l}\text { As you know, U.S. universities offer various opportunities to study abroad in countries such } \\
\text { as China, from spending a semester at a Chinese university to getting a degree at a Chinese } \\
\text { university. Please tell us to what extent you agree with the following statements about } \\
\text { choosing China for a study abroad opportunity: } \\
\text { 1.My parents think it would be good for me to study in China. } \\
\text { 2.My parents would want me to study in China. } \\
\text { 3.My parents would support my wish to study in China. } \\
\text { 4.Most of my friends believe it would be a good thing to study in China. } \\
\text { 5.Most of my friends would want me to study in China. } \\
\text { 6.Most of my friends had good experience if they visited China before (omitted) } \\
\text { 7.Most of my relatives (including parents, siblings etc.) had good experience if they visited } \\
\text { China before. (omitted) }\end{array}$ \\
\hline $\begin{array}{l}\text { Attitudes toward } \\
\text { Studying in China }\end{array}$ & $\begin{array}{l}\text { As you know, U.S. universities offer various opportunities to study abroad in countries such } \\
\text { as China, from spending a semester at a Chinese university to getting a degree at a Chinese } \\
\text { university. Please tell us to what extent you agree with the following statements about } \\
\text { choosing China for a study abroad opportunity: } \\
\text { 1. I like the idea of studying in China. } \\
\text { 2. My attitude toward studying in China is positive. } \\
\text { 3. Generally, I believe that it would be good for me to study in China. } \\
\text { 4. Honestly, I don't like the idea of studying in China. (Reversely coded) }\end{array}$ \\
\hline $\begin{array}{l}\text { Intent to study in } \\
\text { China }^{6}\end{array}$ & $\begin{array}{l}\text { As you know, U.S. universities offer various opportunities to study abroad in countries such } \\
\text { as China, from spending a semester at a Chinese university to getting a degree at a Chinese } \\
\text { university. Please tell us to what extent you agree with the following statements about } \\
\text { choosing China for a study abroad opportunity: } \\
\text { 1. I intend to study in China in a year or so. } \\
\text { 2. I am planning to apply to some Chinese universities in a year or so. } \\
\text { 3. I am learning Chinese to prepare for my future study in China. } \\
\text { 4. I would recommend studying in China to my friends. }\end{array}$ \\
\hline
\end{tabular}

Note: All response options ranged from 1, "strongly disagree" to 5, "strongly agree" if not provided.

${ }^{1}$ Developed for this study based on previous studies.

${ }^{2}$ An integrated scale adapted from the Reputation Institute's (2012) Country RepTrak Scale, Passow et al.'s (2005) Country

Reputation Index, and Yang et al.'s (2008) Country Reputation Scale.

${ }^{3}$ Developed based on Passow et al. (2005) and Yang et al. (2008).

${ }^{4}$ Developed by the authors based on Fitzsimmons et al. (2013), Presley et al. (2012), \& Schnusenberg et al. (2012).

${ }^{5}$ Developed by the authors based on previous studies (e.g., Yang \& Wang, 2017).

${ }^{6}$ Developed by the authors based on previous studies (e.g., Yang \& Wang, 2017). 